\title{
Erratum on Influence of biogenic secondary organic aerosol formation approaches on atmospheric chemistry
}

B. Bonn, R. von Kuhlmann and M. G. Lawrence

Max-Planck-Institute for Chemistry, Atmospheric Chemistry Division, Mainz, Germany

The article 'Influence of biogenic secondary organic aerosol formation approaches on atmospheric chemistry' (J. Atmos. Chem, 51, pp. 235-270) was submitted, accepted, and intended to be published under the names B. Bonn, R. von Kuhlmann, and M. G. Lawrence. Unfortunately, the name of Rolf von Kuhlmann, who was supposed to eventually be listed with a new current affiliation, was instead accidentally dropped in the final revision and typesetting stage. Although the online article can no longer be modified, we would like to request that wherever possible the article be cited in its properly intended form as 'B. Bonn, R. von Kuhlmann and M. G. Lawrence (2005), Influence of biogenic secondary organic aerosol formation approaches on atmospheric chemistry. J. Atmos. Chem., 51, 235-270'. 